\title{
Insight
}

CHI. \& WTO ReV. 2017:1; 169-174

http://dx.doi.org/10.14330/cwr.2017.3.1.09

pISSN 2383-8221 • elSSN 2384-4388

China and WTO Review

\section{THAAD and China's Trade Policy with South Korea}

Xiangqian Gong*

Associate Professor at Beijing Institute of Technology Law School

\section{Introduction}

Over the past year, China has launched a series of trade measures against South Korea, including the anti-dumping investigations to POM plastic and polycrystalline silicon, the extending of anti-dumping duties upon single-mode fiber, among others. Recently, 19 batches of cosmetics made in Korea were not allowed to enter the Chinese market. Even more, the plans for two Korean classical musicians' performances in China were suspended. The media interpreted those incidents as China's retaliation against South Korea's decision to deploy the Terminal High Altitude Area Defense ("THAAD") anti-missile system.

THAAD is likely to harm trade between China and South Korea in the long run, as political stability is the basic condition for smooth economic cooperation. However, we have to point out that the Korean cosmetics were banned because the submitted proof of import materials was not sufficient. As for the cancellation of musicians' visit to China, there are no open Chinese documents and policies which purport to curtail culture exchange between China and South Korea. On February 1, 2017, the PRC Ministry of Trade, Industry and Energy announced that South Korea's exports to China jumped 13.5 percent, the first double-digit growth in 41 months. ' In fact, South Korea also imposed many trade measures, e.g., anti-dumping duties on Chinese offset. When 2200 tons of garlic from Shandong China was rejected by South Korean customs in 2015, the media also mistakenly interpreted the matter as malicious prohibition from Korea. ${ }^{2}$

* Ph.D.(Wuhan). 


\section{China's Dilemma and its Rational Response to THAAD}

The disagreement between China and South Korea on the nuclear issue has always been a major obstacle to bilateral relations. South Korea hopes that China will be able to show more substantial policy adjustment to North Korea's nuclear program, but China preferred to regional stability. The whole international community must recognize that China is not able to fully control another sovereign State's nuclear weapons development program. Moreover, Chinese officials would generally regard the presence of North Korea as a strategic pawn of China in Northeast Asia. China has often been put in a strategic dilemma by North Korea which has become a de facto nuclear country. It is too late for China to take any unilateral action to make Kim Jong-un give up the nuclear program. China opposes THAAD mainly because it will not be very effective in averting the North Korean nuclear and missile threat for the geographical proximity, but will instead assist the US to deploy its missile defense system in Asia-Pacific region, which is detrimental to peace and security of Northeast Asia as a whole. ${ }^{3}$ South Korea already acknowledged in May 2013 that it "has its own missile defense system for uses against missiles in the terminal stage, which is best suited for countering growing North Korean missile threats."

When South Korea began to consider deploying THAAD in 2014, China attempted to prohibit trade and economic exchanges with South Korea. China's policy was basically to take economic interests based on strategic trust. On December 20, 2015, the China-South Korea Free Trade Agreement came into effect. This bilateral FTA, which covers e-commerce, government procurement and a raft of other new trade issues, is expected to form a common market with a total GDP of up to USD 12 trillion. ${ }^{5}$ It is an objective fact that South Korea's economic dependence on China goes far beyond China's need for Korea. ${ }^{6}$ If China imposes extreme economic sanctions such as banning all Korean products from selling in China, Korea's economy could face a risk of collapse. For the time being, South Korea has not succumbed to the Chinese government's protest, which has prolonged China's fierce reaction. Obviously, China decides not to threaten, but only to warn South Korea. Most the trade measures against South Korea are basically in line with international law. The good sign is that the 11th round of China-Japan-South Korea Free Trade Agreement ("CJK FTA") negotiations was 
held in Beijing on January 9-11, 2017. Once THAAD becomes a reality on the Korean peninsula, no one can be optimistic about the further negotiations of the CJK FTA.

As another initiative, China has established the Asian Infrastructure Investment Bank ("AIIB"). It is a serious challenge to the existing international and regional economic arrangements that are largely dominated by the West and Japan. South Korea has formally expressed its hope to host the AIIB headquarters in Seoul or Songdo international city. Although the US wanted South Korea to keep away from it, China succeeded in getting South Korea on board by offering it a founding member status. However, South Korea, Japan, Australia and Indonesia did not participate in the signing ceremony of the AIIB Agreement, which reflects these member States' concerns of the US, and is in line with an ostensible 'balance strategy' between China and the US.

\section{Possible Political and Legal Resolution Framework}

The Korean Peninsula is geopolitically critical where the hegemonic interests of major powers are mutually crossing. North Korea's nuclear weapons development is a high risk to the balance of power. In this regard, deployment of THAAD in South Korea will exacerbate the status quo. China imposed unprecedented economic sanctions on North Korea in 2016. ${ }^{7}$ China thinks that "the issue of missile defense system concerns global strategic stability and mutual trust between major countries." ${ }^{8}$ In order to prevent THAAD, consequently, it is urgently needed to deepen the dependence and trust between the two countries. Existing integrative measures such as the China-Korea FTA and the AIIB should be accelerated and bolstered. In addition, a nuclear umbrella can be provided for South Korea under the auspices of the US with the participation of China, which, in fact, is in line with China and South Korea's common security interests. The US, which has mastered the strategic initiative, should not misunderstand China's own concern of security, but assume the responsibility to suppress and prevent Kim Jong-un's adventure to go nuclear. Instead of deploying THAAD, South Korea may also try to develop its own missile defense system.

State practice of both China and South Korea in the WTO dispute settlement mechanism has shown that the two sides can handle trade disputes related to the 
international rules in a reasonable, effective, and moderate manner. On January 16, 2017, the Deputy Prime Minister of South Korea said, "The government will try to promote dialogue and persuasion through a number economic cooperation channels to ease the impact of THAAD, but if the trade measure is contrary to international norms of trade issues, there will be a positive response." ${ }^{9}$ On one side, China should welcome the trade dispute settlement within a legal framework, while, on the other side, it should try to resolve the THAAD issue through negotiation under international law. The following should be kept in mind. First, the operation of THAAD will violate international law if it orbits or installs nuclear weapon, or breaks the rules of the UN Charter and environmental laws. Second, China can raise a question whether the US-ROK Joint Defense Treaty is a collective self-defense under Article 51 of the UN Charter. According to Wang Yi, the Chinese Foreign Minister, the coverage of THAAD, especially the monitoring range of its X-band radar, goes far beyond the defense need of the Korean Peninsula and will reach deep into the Asian hinterland. ${ }^{10}$

\section{Conclusion}

China's recent trade measures against South Korea should not be over-interpreted, although THAAD's deployment will undoubtedly impact on the overall economic and trade relations between China and South Korea and may even worsen the South Korean economy in the end. On the whole, China is strategically deepening its economic relations and trade with South Korea under international law. South Korea's best choice is to seek multilateral cooperation and protection from both the US and China together. Whatsoever, South Korea rational choice would be to refuse THAAD and maintain stability with the US and China comprehensively.

\section{REFERENCES}

1. ROK Ministry of Trade, Industry and Energy, Korean exports surge 11.2\% in January, Press Releases (Feb. 1, 2017), available at http://english.motie.go.kr/en/pc/pressreleases/bbs/ bbsView.do?bbs_seq_n $=513 \& b b s \_c d \_n=2 \&$ currentPage $=1 \&$ search_key_n $=\&$ search_val_ $\mathrm{v}=$ \&cate_n $=$ (last visited on Feb. 6, 2017).

2. Wenbing Zhao, Is Garlic Return Normal or Occasional - Observation on the Sino - Korean 
Trade Friction 大蒜退运是常态还是偶发-中韩贸易摩擦观察, CHINA BORDER TIMES 中国国门时报, Mar. 4, 2015, available at http://cngm.cqn.com.cn/html/2015-03/04/node_21.htm (last visited on Feb. 6, 2017).

3. See China and Russia signed a joint statement on strengthening global strategic stability, XinhuANet, June 26, 2016, available at http://news.xinhuanet.com/english/2016-06/26/ c_135466187.htm (last visited on Feb. 6, 2017).

4. NTI, South Korea Still Not Joining U.S. Missile Defense System, available at http://www.nti. org/gsn/article/south-korea-still-not-joining-us-missile-defense-system (last visited on Feb. 6, 2017).

5. Ji-sook Bae, Korea, China sign free trade agreement, Korea Herald, June 1, 2015, available at http://www.koreaherald.com/view.php?ud=20150601001162 (last visited on Feb. 6, 2017).

6. S. Denney, South Korea's Economic Dependence on China, Diplomat, Sept. 4, 2015, available at $\mathrm{http}: / /$ thediplomat.com/2015/09/south-koreas-economic-dependence-on-china (last visited on Feb. 7, 2017).

7. "For the implementation of the relevant UN Security Council resolutions, Articles 16 and 18 of the PRC Foreign Trade Law prohibit the export the weapons of mass destruction and their delivery vehicles to the DPRK. See Notice of the Ministry of Commerce, the Ministry of Industry and Information Technology, the National Defense Science and Industry Bureau, the State Atomic Energy Agency, and the General Administration of Customs No. 2017 商务 部、工业和信息化部、国防科工局、国家原子能机构、海关总署公告 2017年第 9号, available at http://www.mofcom.gov.cn/article/b/e/201701/20170102507933.shtml; Announcement of the Ministry of Commerce and the General Administration of Customs on the Listing of Certain Mineral Products Prohibited from DPRK (No. 11, 2016) 商务部 海关总署2016年第 11号公 告 关于对朝鲜禁运部分矿产品清单公告, available at http://www.mofcom.gov.cn/article/b/e/ 201604/20160401289770.shtml (all last visited on Feb. 6, 2017).

8. Statement by Ambassador Wang Qun, Director-General of the Arms Control Department of the Ministry of Foreign Affairs of China, at the General Debate of the First Committee of the 71st Session of the UNGA, Oct. 10, 2016, available at http://www.fmprc.gov.cn/ce/ceun/eng/ hyyfy/t1408974.htm (all last visited on Feb. 6, 2017).

9. Vice Prime Minister of South Korea: Deal with China's Trade Restrictions in accordance with International Norms 韩副总理: 依据国际规范应对中国限贸, YonHAP News, Jan 16, 2017, available at http://chinese.yonhapnews.co.kr/newpgm/9908000000.html?cid=ACK2017011 6004900881 (last visited on Feb. 6, 2017).

10. On February 12, 2016, after attending the fourth foreign ministers' meeting of the International Syria Support Group (ISSG) in Munich, Germany, Foreign Minister Wang Yi gave an exclusive interview to Reuters, answering questions relating to the Korean Peninsula nuclear issue. See WangYi Talks about Principles China Upholds in Dealing with the Korean Peninsula Nuclear Issue, PRC Ministry of Foreign Affairs, Feb. 13, 2016,

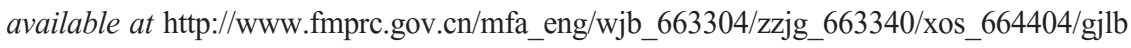
_664408/3296_664550/3298_664554/t1340527.shtml (last visited on Feb. 6, 2017). 
